\title{
PERTUMBUHAN IKAN KERALI (Labocheilos falchifer) DI PERAIRAN SUNGAI LEMATANG, SUMATERA SELATAN
}

\begin{abstract}
Marson $^{1)}$ dan Mas Tri Djoko Sunarno ${ }^{2)}$
1) Peneliti pada Balai Riset Perikanan Perairan Umum, Mariana-Palembang

2) Peneliti pada Pusat Riset Perikanan Tangkap-Jakarta

Teregristrasi I tanggal: 11 Juli 2008; Diterima setelah perbaikan tanggal: 21 Juli 2008; Disetujui terbit tanggal: 28 Juli 2008

ABSTRAK

Ikan kerali (Labocheilos falchifer) merupakan salah jenis ikan endemik di perairan Sungai Lematang, Sumatera Selatan. Untuk pengeloaan suatu jenis ikan, salah satunya dibutuhkan pengamatan pertumbuhan ikan tersebut. Oleh karena itu, suatu penelitian telah dilakukan untuk mengamati pertumbuhan ikan kerali di Sungai Lematang pada bulan Maret 2008. Stasiun pengamatan ditetapkan secara sengaja di Sungai Lematang dan anak-anak sungainya, yaitu Sungai Mulak, Selangis, dan Ndikat. Ikan contoh ditangkap dengan alat jala (cast net) dan jaring (gill net). Ikan contoh diukur panjang dan bobot. Analisis hubungan bobot tubuh dengan panjang total ikan kerali di semua perairan Sungai Lematang (sungai utama dan anak sungainya) menunjukkan pertumbuhan alometrik positif.
\end{abstract}

KATAKUNCI: $\quad$ pertumbuhan, ikan kerali, Labocheilos falchifer, Sungai Lematang

\section{PENDAHULUAN}

Sungai Lematang merupakan salah satu anak sungai terbesar dari Sungai Musi, terletak di bagian hulu, mengalir di Kabupaten Lahat Propinsi Sumatera Selatan. Sungai ini memiliki arus deras, dasar perairan berpasir dan berbatu terutama di bagian hulu. Sungai Lematang dimanfaatkan oleh masyarakat sebagai sumber mata air, transportasi, irigasi, mineral, dan perikanan. Berdasarkan pada catatan Weber \& Beaufort (1916) dan; Utomo et al. (2007), ikan semah (Labeobarbus spp.) merupakan ikan endemik di perairan Musi bagian hulu, termasuk Sungai Lematang. Selain itu, ikan endemik lainnya yang ditemui di perairan tersebut dan mempunyai nilai ekonomis penting di Kabupaten Lahat, Sumatera Selatan adalah ikan kerali (Labocheilos falchifer) (Gambar 1).

Vegetasi di sepanjang perairan Lematang merupakan produsen primer yang menyediakan bahan organik bagi ikan (Gaffar \& Fatah, 2006). Di samping itu, batu-batuan yang ditumbuhi lumut yang berada pada perairan tersebut merupakan tempat bagi ikan- ikan untuk mencari makan. Tumbuhan air juga berfungsi sebagai pelindung (shelter) dan tempat menempelkan telur pada saat ikan memijah. Oleh karena itu, Utomo et al. (1993) mengatakan bahwa di daerah hutan rawa air tawar mempunyai potensi sumber daya ikan lebih tinggi dibandingkan perairan tipe lainnya.

Sungai Lematang mempunyai banyak cabang sungai yang bermuara di sungai tersebut. Karakteristik habitat bagian hulu yang diutarakan oleh Utomo et al. (1993) terlihat di perairan Lematang. Ciri-ciri antara lain berarus deras, berbatu, berpasir pada dasar sungai, mempunyai kecerahan yang tinggi, nilai $\mathrm{pH}$ berkisar 7,0-7,5, suhu air relatif rendah, dan kandungan oksigen terlarut tinggi. Salah satu anakanak sungai tersebut adalah Sungai Mulak, Selangis, Lematang, dan Ndikat.

Pola pertumbuhan suatu jenis ikan bergantung pada kondisi lingkungan dan sediaan makanan. Pada kondisi lingkungan cocok dan sumber makanan melimpah, ikan akan tumbuh tidak terbatas dan dapat berkembang biak dengan baik. Pertumbuhan akan

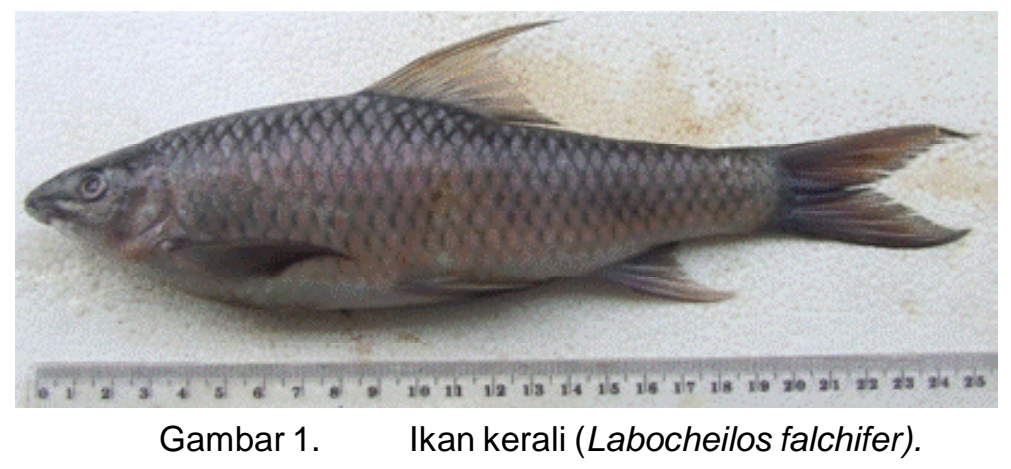


terganggu pada saat sediaan makanan terbatas dan atau peningkatan intensitas tekanan terhadap populasi ikan tersebut misalnya penangkapan ikan dewasa yang sedang melakukan ruaya pemijahan. Jika kedua faktor tersebut berjalan secara pararel, pertumbuhan akan terganggu. Salah satu indikatornya adalah dengan mengetahui sebaran panjang dan bobot serta hubungan keduanya (Royce, 1984).

Penelitian ini bertujuan untuk mengetahui pola pertumbuhan ikan kerali yang hidup di perairan Sungai Lematang, Sumatera Selatan dengan cara menganalisis hubungan panjang total dengan bobot tubuh ikan tersebut.

\section{BAHAN DAN METODE}

Penelitian ini dilakukan pada bulan Maret 2008. Stasiun pengamatan ditetapkan secara sengaja di empat tempat, yaitu sungai utama (Sungai Lematang) dan anak-anak sungai yang bermuara di Sungai Lematang, yaitu Sungai Mulak, Selangis, dan Ndikat (Gambar 2). Penelitian ini dilakukan dengan metode pengamatan langsung. Contoh ikan kerali diperoleh dari hasil tangkapan nelayan dengan menggunakan beberapa alat tangkap seperti jala (cast net) dan jaring (gill net). Ikan kerali yang tertangkap diidentifikasi dengan menggunakan Weber \& Beaufort (1916). Pengamatan parameter kualitas perairan juga dilakukan di empat stasiun tersebut. Parameter yang diamati adalah suhu udara, suhu air, kandungan oksigen terlarut (DO), kandungan $\mathrm{CO}_{2}$ bebas, kecepatan arus, $\mathrm{pH}$, kedalaman, kecerahan, alkalinitas, kondustivitas, biochemical oxygen demand (BOD) 5 hari, dan total dissolved solid (TDS).

Contoh ikan diukur panjang total dengan penggaris baja (ketelitian 0,01) dan ditimbang bobot dengan timbangan manual (ketelitian 0,1). Hubungan bobot tubuh dengan panjang total ikan kerali ditentukan berdasarkan pada rumus Royce (1984) yaitu:

$\mathrm{W}=\mathrm{a} \mathrm{L}^{\mathrm{b}}$ $(1$

di mana:

$\mathrm{W}=$ bobot ikan $(\mathrm{g})$

$\mathrm{L} \quad \quad=$ panjang total ikan $(\mathrm{mm})$

$\mathrm{a}$ dan $\mathrm{b}=$ konstanta regresi eksponensial

Analisis data secara deskriptif dalam bentuk tabulasi dan grafik.

\section{HASIL DAN BAHASAN}

Sungai Lematang merupakan anak sungai terbesar dari Sungai Musi yang terletak di bagian hulu. Sungai ini memiliki arus deras dan di berbagai tempat terdapat batu-batu besar terutama di bagian hulu. Selain sumber daya perikanan, Sungai Lematang digunakan juga sebagai sumber mata air, transportasi, irigasi, dan penambangan mineral. Vegetasi akuatik menyediakan lahan reproduksi dan makanan bagi

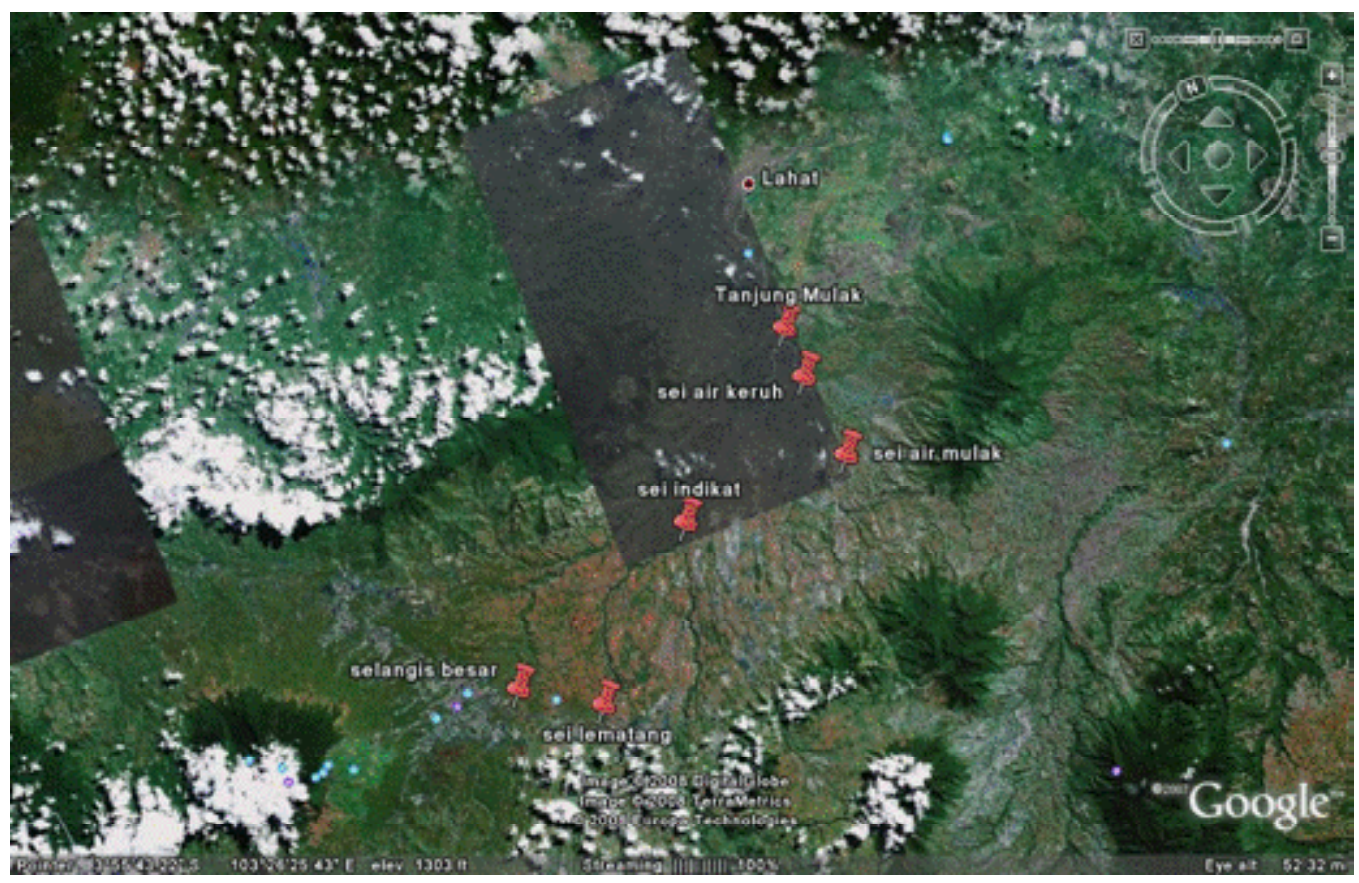

Gambar 2. Lokasi penelitian ikan kerali (Labocheilos falchifer) di Sungai Lematang Sumatera Selatan. Sumber: www.googlemap.com 
ikan, dalam hal ini menyediakan substrat sebagai tempat meletakkan telur dan makanan dari berbagai jenis substansi baik insekta (carnivora) maupun buah dan rumputan (herbivora) (Scalet et al., 1996). Sungai Lematang ini mempunyai beberapa anak sungai yang bermuara di sungai tersebut, antara lain Sungai Mulak, Selangis, dan Ndikat. Vegetasi di Sungai Lematang dan anak-anak sungai tersebut relatif sama.

Hasil pengamatan kualitas air di stasiun pengamatan masing-masing di Sungai Mulak, Selangis, Lematang, dan Ndikat dapat dilihat pada Tabel 1. Pada saat pengamatan, cuaca dalam kondisi cerah. Kedalaman air berkisar $75-200 \mathrm{~cm}$. Kecepatan arus di Sungai Lematang $(1,01 \mathrm{~m}$ per detik) lebih rendah dibandingkan dengan anak sungai tersebut, berkisar 0,19-0,50 $\mathrm{m}$ per detik. Tingkat kecerahan air terendah diamati di Sungai Selangis $(25 \mathrm{~cm})$ dan tertinggi di Sungai Ndikat $(125 \mathrm{~cm})$. Suhu air di ketiga anak sungai adalah relatif sama $\left(25^{\circ} \mathrm{C}\right)$, kecuali di sungai utama (Sungai Lematang), suhunya lebih rendah $\left(24^{\circ} \mathrm{C}\right)$.

Rendahnya suhu di Sungai Lematang diikuti oleh nilai oksigen terlarut (DO) yang lebih rendah $(7,04$ $\mathrm{mg} / \mathrm{L}$ ) dibandingkan dengan anak sungai. Kandungan $\mathrm{CO}_{2}$ bebas tidak berbeda antara Sungai Lematang dan Selangis (4,4 mg/L) dan lebih rendah dibandingkan dengan Sungai Mulak dan Ndikat (6,6 mg/L). Nilai pH perairan di semua stasiun pengamatan berkisar 7,07,5. Secara keseluruhan, kondisi kualitas air dan lingkungan di semua stasiun pengamatan dapat menunjang hidup dan kehidupan jasad akuatik, termasuk ikan kerali.
Hasil pengamatan terhadap mutu air pada masingmasing stasiun pengamatan secara umum menunjukkan kisaran netral sampai agak alkalis, namun dalam batas toleransi kehidupan ikan kerali. Nilai $\mathrm{pH}$ pada stasiun pengamatan Sungai Lematang cenderung bersifat basa, bila dibandingkan dengan $\mathrm{pH}$ pada stasiun pengamatan Sungai Mulak, Selangis, dan Ndikat. Hal ini mengindikasikan bahwa ketersediaan oksigen yang tinggi mencapai 7,04 ppm di mana air sungai mengalir dengan kecepatan mencapai 1,01 m per detik.

Kapasitas perairan Sungai Lematang menetralkan tambahan asam tanpa menurunkan $\mathrm{pH}$ air mencapai $21 \mathrm{mg} / \mathrm{L}$ hal ini lebih baik dibandingkan dengan alkalinitas pada stasiun Sungai Mulak, Selangis dan Sungai Ndikat. Hal ini mengindikasikan adanya $\mathrm{CO}_{2}$ yang rendah $(4,4 \mathrm{mg} / \mathrm{L})$. Keadaan ini lebih baik dibanding $\mathrm{CO}_{2}$ yang terdapat pada stasiun Sungai Mulak dan Ndikat.

Kecerahan dan total dissolved solid (TDS) pada stasiun Sungai Lematang cenderung lebih baik bila dibandingkan dengan stasiun Sungai Mulak, Selangis, dan Ndikat. Berdasarkan pada karakteristik mutu perairan di atas dapat dikatakan bahwa perairan yang demikian dapat mendukung sifat pertumbuhan yang berimbang bagi kehidupan ikan kerali.

Hubungan panjang dan bobot ikan kerali di setiap stasiun pengamatan dapat dilihat pada Tabel 2 dan Gambar 3. Persamaan regresi hubungan panjang total dan bobot tubuh pada masing-masing stasiun diperoleh nilai b terbesar $(3,306)$ pada stasiun Sungai

Tabel 1. Hasil pengukuran beberapa parameter kualitas air di stasiun penelitian

\begin{tabular}{lcccc}
\hline \multirow{2}{*}{ Parameter } & \multicolumn{4}{c}{ Stasiun pengamatan } \\
\cline { 2 - 5 } & Sungai Mulak & Sungai Selangis & Sungai Lematang & Sungai Ndikat \\
\hline Suhu Udara $\left({ }^{\circ} \mathrm{C}\right)$ & 28 & 28 & 31 & 27 \\
Suhu Air $\left({ }^{\circ} \mathrm{C}\right)$ & 25 & 25 & 24 & 25 \\
Oksigen terlarut $(\mathrm{mg} / \mathrm{L})$ & 7,36 & 7,23 & 7,04 & 7,55 \\
$\mathrm{CQ}(\mathrm{mg} / \mathrm{L})$ & 6,6 & 4,4 & 4,4 & 6,6 \\
$\mathrm{pH}$ & 7,0 & 7,0 & 7,5 & 7,0 \\
Kecepatan Arus (m/det) & 0,38 & 0,19 & 1,01 & 0,50 \\
Kedalaman air $(\mathrm{cm})$ & 200 & 75 & 100 & 150 \\
Kecerahan $(\mathrm{cm})$ & 75 & 25 & 75 & 125 \\
Alkalinitas $(\mathrm{mg} / \mathrm{L})$ & 11,5 & 11,0 & 21,0 & 11,5 \\
Conductivity $(\mathrm{umHos})$ & 60 & 80 & 100 & 140 \\
BOD $(\mathrm{mg} / \mathrm{L})$ & 1,09 & 0,19 & 0,32 & 0,58 \\
TDS $(\mathrm{mg} / \mathrm{L})$ & 30 & 40 & 50 & 70 \\
Cuaca & Cerah & Cerah & Cerah & Cerah $^{\prime}$ \\
Posisi & & & & \\
Selatan & $03^{\circ} 59^{\prime} 03.3^{\prime \prime}$ & $04^{\circ} 02^{\prime} 34.6^{\prime \prime}$ & $04^{\circ} 04^{\prime} 21.0^{\prime \prime}$ & $03^{\circ} 59^{\prime} 06.1^{\prime \prime}$ \\
Timur & $103^{\circ} 31^{\prime} 34.2^{\prime \prime}$ & $103^{\circ} 16^{\prime} 29.3^{\prime \prime}$ & $103^{\circ} 19^{\prime} 19.3^{\prime \prime}$ & $103^{\circ} 24^{\prime} 50.7^{\prime \prime}$ \\
\hline
\end{tabular}


Lematang, sedangkan nilai b terkecil $(2,887)$ pada stasiun Sungai Mulak. Hasil pengujian nilai b diperolah nilai lebih kecil dari 3. Artinya, pertumbuhan ikan kerali tergolong allometrik negatif di mana pertumbuhan panjang lebih cepat dibandingkan pertumbuhan bobot. Dari empat stasiun yang dianalisis statistik hubungan panjang total dengan bobot tubuh ternyata stasiun Sungai Lematang, Selangis, dan Ndikat mempunyai nilai b lebih besar dari 3, maka ketiga stasiun tersebut merupakan habitat terbaik bagi ikan kerali di perairan Lematang.
Hubungan panjang bobot ikan kerali di daerah aliran Sungai Lematang bersifat allometrik positif. Dari hasil penelitian sifat pertumbuhan ikan kerali di Sungai Lematang, Selangis, dan Ndikat didapatkan perbedaan BOD dan kedalaman air yang nyata dibandingkan dengan stasiun Sungai Mulak (Tabel 1). BOD dan kedalaman akan mempengaruhi proses fotosentesis. Proses fotosintesis akan terganggu dengan kondisi perairan yang dalam.

Tabel 2.

Persamaan regresi hubungan panjang dan bobot ikan kerali di masing-masing stasiun

\begin{tabular}{lccc}
\hline \multicolumn{1}{c}{ Stasiun pengamatan } & $\begin{array}{c}\text { Hubungan panjang (L) } \\
\text { dan bobot (W) }\end{array}$ & Jumlah contoh (ekor) & Koefisien korelasi (r) \\
\hline Sungai Lematang & $\mathrm{W}=0,003 \mathrm{~L}^{3.306}$ & 34 & 0,957 \\
Sungai Mulak & $\mathrm{W}=0,013 \mathrm{~L}^{2.887}$ & 30 & 0,745 \\
Sungai Ndikat & $\mathrm{W}=0,007 \mathrm{~L}^{3.073}$ & 50 & 0,922 \\
Sungai Selangis & $\mathrm{W}=0,004 \mathrm{~L}^{3.211}$ & 37 & 0,954 \\
\hline
\end{tabular}

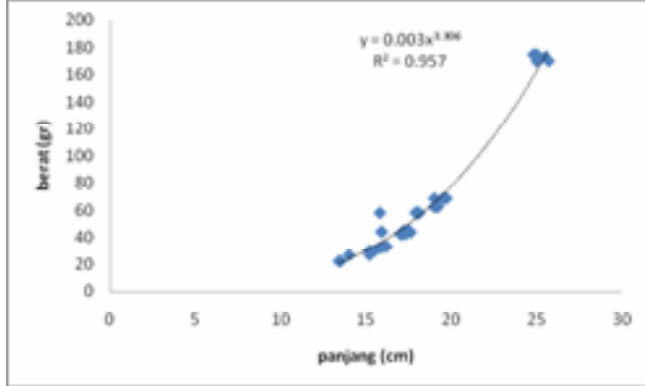

Stasiun Sungai Lematang

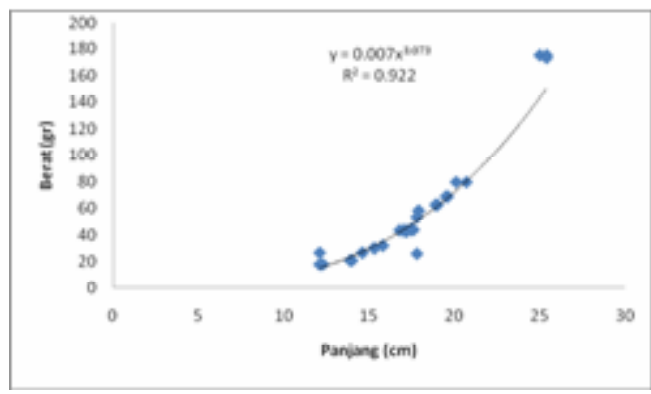

Stasiun Sungai Ndikat

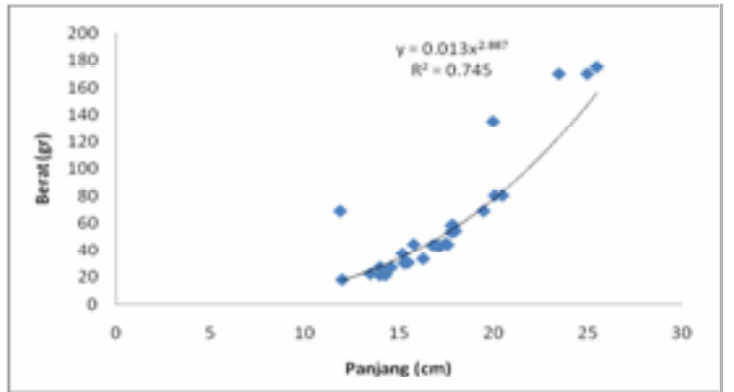

Stasiun Sungai Mulak

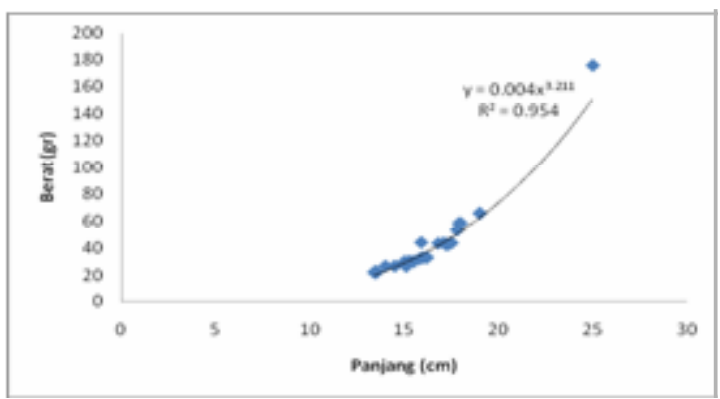

Stasiun Sungai Selangis

Gambar 3. Sifat pertumbuhan ikan kerali (L. falchifer) di setiap stasiun pengamatan.

\section{KESIMPULAN}

Hubungan panjang bobot ikan kerali di Sungai Lematang, Selangis, dan Ndikat bersifat allometrik positif, sedangkan di Sungai Mulak bersifat alometrik negatif. Di Sungai Mulak didapatkan perbedaan BOD dan kedalaman yang nyata. Perbedaan biochemical oksigen deman dan kedalaman air akan mempengaruhi tingkat pertumbuhan populasi ikan yang hidup di stasiun Sungai Mulak, sehingga mengalami pertumbuhan yang tidak sehat (allometrik negatif).

\section{PERSANTUNAN}

Kegiatan dari hasil riset karakteristik habitat dan keanekaragaman plasma nutfah ikan semah (Labeobarbus spp.), T. A. 2008, di Balai Riset 
Perikanan Perairan Umum. Saya ucapkan terima kasih pada Adarmansya, mewakili para nelayan serta semua rekan-rekan yang membantu dalam pencatatan dan pengukuran data.

\section{DAFTAR PUSTAKA}

Gaffar, A. K. \& K. Fatah. 2006. Hubungan panjang bobot dan faktor kondisi beberapa jenis ikan di perairan rawa banjiran Sungai Musi. Prosiding Seminar Nasional Forum Perairan Umum Indonesia III. p. 29-33.

Royce, W. F. 1984. Introduktion Fisheries to the Practice of Fishery Science. Academic Press. California. USA.

Scalet, C. G., L. D. Flake, \& D. W. Wilis. 1996. Introduction to Wildlife and Fisheries, an Integrated Approach, Freeman, and Company. USA. 512 pp.
Utomo, A. D., Z. Nasution, \& S. Adjie. 1993. Kondisi ekologi dan potensi sumber daya perikanan sungai dan rawa di Sumatera Selatan. Prosiding Temu Karya IImiah Perikanan Perairan Umum. Pengkajian Potensi dan Prospek Pengembangan Perairan Umum Sumatera Selatan. Pusat Penelitian dan Pengembangan Perikanan. Jakarta. p. 46-61.

Utomo, A. D., N. Muflikhah, S. Nurdawati, M. F. Raharjo, \& S. Makmur. 2007. Icthiofauna Sungai Musi Sumatera Selatan. Balai Riset Perikanan Perairan Umum. 73 pp.

Weber, M. \& L. F. D. Beaufort. 1916. The Fishes of the Indo Australian Archipelago. Book III. Leiden. E. J. Brill Ltd. Jilid III.

www.googlemap.com. Tanggal 28 Maret 2008. 